\title{
Immunoblotting for the Serodiagnosis of Helicobacter pylori Infection in Brazilian Patients with and without Gastric Carcinoma
}

\author{
Andreia MC Rocha, Gifone A Rocha, Janise L Leite, Renato LL Lisboa, Patrícia VO Silva, \\ Dulciene M M Queiroz ${ }^{+}$
}

\author{
Laboratório de Bacteriologia, Faculdade de Medicina, Universidade Federal de Minas Gerais. Av. Alfredo Balena, 190/4026, \\ 30130-100 Belo Horizonte, MG, Brasil
}

We evaluated the performance of a commercial immunoblotting in the serodiagnosis of Helicobacter pylori infection in Brazilian patients. The presence of anti-H. pylori antibodies was also investigated in a group of 20 duodenal ulcer patients after successful treatment. One hundred and ninety one patients were studied. Among the 164 infected patients, 46 had gastric carcinoma. The duodenal ulcer patients were treated with antimicrobial drugs and the eradication of the microorganism was confirmed in all of them one month after the end of the treatment by the ${ }^{13} \mathrm{C}$-urea breath test. Sera were assayed for H. pylori antibodies using the Helicoblot 2.0 (Genelabs Diagnostics, Singapore). The sensitivity, specificity, positive, and negative predictive values of the test were 93.9\%, 92.6\%, $98.7 \%$, and $71.4 \%$, respectively. The sensitivity of the test was similar in patients with (93.5\%) and without (95.7\%) gastric carcinoma. Twenty-four months after the end of the treatment, the band of $116 \mathrm{kDa}$ was still detected in one of the patients. In conclusion, the Helicoblot 2.0 is an accurate test to diagnose $\mathrm{H}$. pylori infection and although it can not be employed to monitor the bacterium eradication, it may be useful for diagnosing past infection, especially in gastric carcinoma patients.

Key words: Helicobacter pylori - H. pylori/diagnosis - immunoblotting

Helicobacter pylori infection is predominantly acquired in childhood (Parsonnet 1995, Bardhan 1997) and in most subjects its long-term course is without complications. Nevertheless, a small percentage of infected subjects develops peptic ulcer disease, gastric carcinoma or mucosa-associated lymphoid tissue lymphoma (NIH 1994, IARC 1994, Wotherspoon 1998). Infected individuals develop an immune response and $\mathrm{IgG}$ antibodies to $H$. $p y$ lori can be detected in serum (Mégraud 1996, Rocha et al. 1998).

The presence of antibodies against $H$. pylori antigens can be evaluated by immunoblotting (Mitchell et al. 1996, Aucher et al. 1998, Yamaoka et al. 1998, Figueiredo et al. 2001, Park et al. 2002). Although expensive and time-consuming, the test seems to be more sensitive than ELISA, especially when the levels of antibodies are low. This is probably due to the fact that the individual bacterial proteins are better exposed, allowing antibodies to bind more easily (Nilsson et al. 1997). The immunoblotting also allows the detection of antibodies to $H$. pylori virulence factors such as CagA and VacA (Yamaoka et al. 1998, Figueiredo et al. 2001, Park et al. 2002).

Commercial serological tests for $H$. pylori diagnosis have different performances in different populations, in part because of the variations in geographical distribution of the strains and in the antigenic preparations of the

Financial support: $\mathrm{CNPq}$ and Fapemig

${ }^{+}$Corresponding author. Fax: + 55-31-3274.2767. E-mail:

dqueiroz@medicina.ufmg.br

Received 3 September 2003

Accepted 21 January 2004 assays (Aucher et al. 1998, Yamaoka et al. 1998, Leung et al. 2001, Figueiredo et al. 2001). Thus, validating serological assays for each population in order to achieve more reliable results is recommended. The aim of the present study was to evaluate the performance of Helicoblot 2.0 in Brazilian patients. We also investigated the presence of anti- $H$. pylori antibodies in a group of 20 duodenal ulcer patients after successful treatment.

\section{PATIENTS AND METHODS}

This project was approved by the Ethics Committee of Hospital das Clínicas, Universidade Federal de Minas Gerais (UFMG), Brazil, and informed consent was obtained from all patients.

We studied 191 patients (105 male and 86 female; mean age, 46.3 years \pm 15.5 ; range from 17 to 95 years), 164 with and 27 without $H$. pylori infection. Among the infected patients, 48 had duodenal ulcer, 46 gastric carcinoma and 70 had gastritis only. All patients without gastric carcinoma were selected among those referred to the Digestive Endoscopy Unit of the University Hospital, UFMG, for evaluation of symptoms related to the upper gastrointestinal tract. Those who had received antibiotic therapy for the eradication of $H$. pylori or antimicrobial drugs during the 2 months before endoscopy, who were taking $\mathrm{H}_{2}$ receptor antagonists or non-steroidal anti-inflammatory drugs or who had portal hypertension, coagulation disorders, or anatomical obstacles preventing endoscopy were not included in the study. The patients with gastric carcinoma were selected among those who had been treated at the Surgical Clinic of University Hospital, UFMG, at Luxemburgo Hospital, and at Mário Penna Hospital of Oncology.

We also evaluated a group of 20 duodenal ulcer $H$. pylori-positive patients ( 13 male, 7 female, mean age 48.5 
years \pm 15.6 , range from 27 to 76 years) treated with clarithromycin $(500 \mathrm{mg}$, bid), furazolidone (200 mg, bid) plus omeprazole $(20 \mathrm{mg}$, om). The eradication of the microorganism was confirmed in all of them one month after the end of the treatment by the ${ }^{13} \mathrm{C}$-urea breath test. To evaluate the antibody response, sera were collected 6 months after the treatment from 12 patients. From the other 8 patients, sera were obtained 1 year $(n=4)$ and 2 years $(n$ $=4$ ) after the end of the treatment.

At endoscopy, biopsy specimens were obtained from the antral and oxyntic gastric mucosa for microbiological and histological study. In patients with gastric carcinoma, gastric mucosa fragments from the antrum and body were obtained from the stomachs removed by gastrectomy. For urease test, one antral fragment was placed in a tube containing Christensen's 2\% urea agar and examined within $24 \mathrm{~h}$ of incubation at $37^{\circ} \mathrm{C}$ for urea hydrolysis. For culture, fragments from the antrum and body were kept in thioglycolate broth (Difco Laboratories, Detroit, MI, US) at $4^{\circ} \mathrm{C}$ for no longer than $1 \mathrm{~h}$ before processing. The tissue specimens were ground in a tissue homogenizer and plated onto Petri dishes containing Belo Horizonte medium (Queiroz et al. 1987) and the plates were incubated at $37^{\circ} \mathrm{C}$ in a microaerobic environment for up to 7 days. Colonies of $H$. pylori were identified by spiral Gram-negative appearance, positive oxidase and catalase tests, and a rapidly positive urease test. For histology, one fragment of the antral mucosa and one fragment of the oxyntic mucosa were fixed in formalin, dehydrated in alcohol and xylene and embedded in paraffin. Five- $\mu$ m thick sections were obtained for the preparation of slides which were stained with hematoxylin-eosin for histological examination and with carbolfuchsin for $H$. pylori identification.

Patients were considered to be $\mathrm{H}$. pylori-positive if both urease test and carbolfuchisin were positive or if the culture was positive, and negative if the three test results were negative.

Venous blood samples $(5 \mathrm{ml})$ were drawn from each patient at the time of endoscopy or surgery. The serum was separated, divided into aliquots and stored at $-20^{\circ} \mathrm{C}$ before testing.

Sera were assayed for $H$. pylori antibodies using the commercial immunoblotting Helicoblot 2.0 (Genelabs Diagnostics, Singapore). Helicoblot 2.0 is a qualitative assay used for the detection of $\operatorname{IgG}$ antibodies specific for different antigens of $H$. pylori in human serum or plasma. The antigen is prepared from a lysate of a strain of $H$. pylori isolated from a patient with peptic ulcer. The proteins from the lysate are electrophoretically separated and transferred to nitrocellulose. The strips contain different H. pylori antigens including: $116 \mathrm{kDa}(\mathrm{CagA}), 89 \mathrm{kDa}$ (VacA), $35 \mathrm{kDa}, 30 \mathrm{kDa}, 26.5 \mathrm{kDa}$, and $19.5 \mathrm{kDa}$. The assay was performed in the Autoblot System 36 (Genelabs) according to the recommendations of the manufacturer of the kit. Briefly, the strips were washed with wash buffer and each strip was incubated for $1 \mathrm{~h}$ with the diluted sample 1:100 in blocking buffer. A serum-positive control and a serum-negative control were used. Following the incubation period, the sera were aspirated and the strips washed three times. Then, the strips were incubated with an anti-human IgG antibody conjugated with alkaline phos- phatase for $1 \mathrm{~h}$. After this step, the conjugate solution was aspirated from each well, the strips were washed three times and incubated with a solution of 5-bromo-4-chloro3 -indoyl-phosphate and nitroblue tetrazolium for $15 \mathrm{~min}$. The reaction was stopped by rinsing the strips several times with distilled water. Finally, the strips were removed from the wells and dried before mounting. Western blotting was considered to be positive for $H$. pylori if any one band at $116 \mathrm{kDa}, 89 \mathrm{kDa}, 35 \mathrm{kDa}$, or if any two bands from among bands of $30 \mathrm{kDa}, 26.5 \mathrm{kDa}$ or $19.5 \mathrm{kDa}$ were present. The analysis of the test was done by two investigators who were unaware of the H. pylori status of the patients.

For the urea breath test, one breath sample was obtained, after a 6-h fast, and an oral dose of urea comprising $75 \mathrm{mg}{ }^{13} \mathrm{C}$-urea was administered to the patient with $100 \mathrm{ml}$ of orange juice. The other sample was collected 30 min after the ingestion of the substrate. The breath samples were analyzed by an isotope selective nondispersive infrared spectrometer (NDIRIS; Wagner Analytical Systems, Bremen, Germany). The results were considered positive when delta over baseline (DOB) was $>4 \%$ o.

The performance of the immunoblotting was evaluated by determining the sensitivity, specificity, and positive and negative predictive values with $95 \%$ confidence intervals. Statistical analysis was performed by using the $\chi^{2}$ or Fisher's exact test for non-parametric values and the Student's $t$ test for comparison of the mean age between the groups. The level of significance was set at $\mathrm{p}<0.05$.

\section{RESULTS}

The characteristics of the patients studied are listed in Table I. A higher frequency of male patients $(p=0.005)$ and a higher mean age $(\mathrm{p}<0.001)$ were observed in the gastric carcinoma group when compared with the other groups.

Anti-H. pylori antibodies were detected in 154 of 164 H. pylori-positive patients (44/48 with duodenal ulcer, 43 / 46 with gastric carcinoma and 67/70 without duodenal ulcer or gastric carcinoma) and in 2 of 27 non-infected patients. The sensitivity, specificity, positive and negative predictive values of the blot for the diagnosis of the infection were 93.9\% (95\% CI: 88.8-96.9\%), 92.6\% (74.298.7\%), $98.7 \%$ (95-99.8\%) and 71.4\% (53.5-84.8\%), respectively.

The sensitivity of the test was similar in patients with duodenal ulcer (91.6\%), gastric carcinoma (93.5\%), and in those without the diseases $(95.7 \%)(\mathrm{p}=0.44)$. No difference was observed in the frequency of the bands of 19.5 $\mathrm{kDa}(\mathrm{p}=0.59), 30 \mathrm{kDa}(\mathrm{p}=0.31), 35 \mathrm{kDa}(\mathrm{p}=0.14)$ and 89 $\mathrm{kDa}(\mathrm{p}=0.29)$ among the three groups, but the band of $116 \mathrm{kDa}$ was more frequently $(\mathrm{p}<0.01)$ observed in patients with duodenal ulcer and gastric carcinoma than in patients without the diseases. In regard to the $26.5 \mathrm{kDa}$ band it was more frequent in patients with gastric carcinoma than in those with gastritis $(\mathrm{p}=0.03)$ (Table II). Although the difference $(\mathrm{p}=0.07)$ did not reach statistical significance, the frequency of this band was also higher in patients with gastric carcinoma than in those with duodenal ulcer.

False-positive results were due to the detection of antibodies to the $116 \mathrm{kDa}$ antigen in one patient and to 
TABLE I

Characteristics of patients studied

\begin{tabular}{lcccc}
\hline & \multicolumn{3}{c}{ Patients } & Hp-negative \\
\cline { 2 - 4 } & \multicolumn{4}{c}{ Hp-positive } \\
\cline { 2 - 5 } & DU & GC & Gastritis & 27 \\
Number & 48 & 46 & 70 & $11 / 16$ \\
Gender (male/female) & $29 / 19$ & $34 / 12$ & $31 / 39$ & $41.4 \pm 13.4$ \\
Mean age \pm SD (years) & $44.8 \pm 12.5$ & $60.0 \pm 14.9$ & $40.3 \pm 13.2$ & $21-73$ \\
Age range (years) & $24-76$ & $33-95$ & $17-78$ & 25 \\
\hline
\end{tabular}

Hp: Helicobacter pylori; DU: duodenal ulcer, GC: gastric carcinoma

TABLE II

Frequency of immunoreactive bands in the serum of patients with positive result in the immunoblotting

\begin{tabular}{|c|c|c|c|c|c|c|}
\hline \multirow{2}{*}{$\begin{array}{l}\text { Helicobacter pylori } \\
\text { positive patients }\end{array}$} & \multicolumn{6}{|c|}{ Immunoreactive bands ( $\mathrm{kDa}$ ) (\% positivity) } \\
\hline & 19.5 & 26.5 & 30 & 35 & 89 & 116 \\
\hline With duodenal ulcer (DU) $(n=44)$ & $14(32)$ & $34(77)$ & $18(41)$ & $25(57)$ & $22(50)$ & $41(93)^{b}$ \\
\hline With gastric carcinoma $(\mathrm{GC})(\mathrm{n}=43)$ & $13(30)$ & $40(93)^{a}$ & $21(49)$ & $33(77)$ & $16(37)$ & $37(86)^{b}$ \\
\hline Without DU and GC $(n=67)$ & $26(39)$ & $50(75)^{a}$ & $38(57)$ & $41(61)$ & $24(36)$ & $40(60)^{b}$ \\
\hline
\end{tabular}

$a: \mathrm{p}=0.02 ; b: \mathrm{p}<0.001$

the $30 \mathrm{kDa}$ and $35 \mathrm{kDa}$ antigens in the other.

The ${ }^{13} \mathrm{C}$-urea breath test was negative in all treated patients. The result of the immunoblotting was positive in all 12 patients in the 6 months follow-up. One year after the end of the treatment only the band of $116 \mathrm{kDa}(\mathrm{CagA})$ could be detected in the sera of the 4 patients evaluated at that time. Sera of the other 4 patients were studied 24 months after the treatment and in only one of them the band of $116 \mathrm{kDa}$ was detected.

\section{DISCUSSION}

Since $H$. pylori infection elicits a systemic, strong and polymorphic humoral immune response (Herbrink \& van Doorn 2000), serological assays have been successfully used for the diagnosis of the infection. Although ELISA is an accurate test, some authors have demonstrated that immunoblotting is more sensitive to detect recent (Mitchell et al. 1996) and previous H. pylori infection (Sörberg et al. 1997), especially in the case of sera with low levels of antibodies (Nilsson et al. 1997). In addition, as the antibodies react with defined antigens, the test allows the simultaneous detection of bacterium virulence factors. However, as there is a high degree of genetic heterogeneity among $H$. pylori strains and, consequently, in the proteins that are surface-exposed or secreted (Go et al. 1996, Herbrink \& van Doorn 2000), the assay must be validated for the population being studied (Mitchell et al. 1996, Aucher et al. 1998, Yamaoka et al. 1998, Figueiredo et al. 2001).

In the present study, employing three tests as gold standard, we validated a commercial blot to diagnose $H$. pylori infection in Brazilian population. Similarly to that we have previously observed for children (Rocha et al. 2000), the assay showed high sensitivity (92.8\%) for the diagnosis of the infection in adults. Other authors, em- ploying the same kit (Yamaoka et al. 1998, Malaty et al. 2002, Park et al. 2002) or in-house techniques (Faulde et al. 1993, Klaamas et al. 1996, Karvar et al. 1997, Nilsson et al. 1997, Holtmann et al. 1998) also reported high sensitivity for the test. In addition, we observed that the sensitivity was similar in patients with duodenal ulcer, gastric carcinoma, and gastritis only. It is an important finding because as demonstrated by Queiroz et al. (1999), the current methods used to diagnose $H$. pylori infection are less sensitive in gastric carcinoma patients, being recommended the association of at least a direct and an indirect test in these patients. In fact, as the infection may have disappeared by the time the cancer is diagnosed, the detection of antibodies, especially anti-CagA, can be the unique positive method (Ekström et al. 2001).

Similarly to the data of other authors employing the same kit (Yamaoka et al. 1998, Malaty et al. 2002) or inhouse blot (Nilsson et al. 1997), we observed 2 false-positive results. This may be due more to the use of antimicrobial drugs for other purpose with a resulting decrease in bacterial load or spontaneous bacterium elimination with persistence of antibodies than detection of cross-reacting antibodies. This hypothesis is strengthened by the detection of the $116 \mathrm{kDa}$ band $(\mathrm{CagA})$ in the serum of 1 of the 2 patients, once this antibody lasts longer after bacterium eradication. On the other hand the specificity we observed was higher than that described by Karvar et al. (1997) (specificity of 71\%) and Aucher et al. (1998) (specificity of $82 \%$ ), employing in-house techniques. These differences may be due to the gold standard used and the criteria adopted to establish negativity. We employed 3 methods for diagnosing infection and rigid criteria for negativity, which limits erroneous classification of the patients as $H$. pylori negative. Although the exact antigen composition of the Helicoblot 2.0 was not provided 
by the manufacturer, the assay is based on Western-blot analysis of whole-cell $H$. pylori strain NCTC 11916 antigens (Figueiredo et al. 2001, Park et al. 2002) and differences in preparation of the antigen can also justify the differences observed in the specificity of the tests.

Although the positive predictive value of the assay was high (98.7\%), the negative predictive value was not $(71.4 \%)$. This finding may be due to the small proportion of uninfected patients evaluated in the present study.

In agreement with the results obtained in other western populations (Crabtree et al. 1993, Klaamas et al. 1996, Holtmann et al. 1998), in the present study, serum antiCagA antibodies were detected more frequently in gastric carcinoma and duodenal ulcer patients than in $\mathrm{H}$. pyloripositive patients without these diseases. Infection with cagA-positive strains has been associated with higher degree of gastric mucosa inflammation, a risk for the development of the diseases associated with infection.

We also observed a higher frequency of the band of $26.5 \mathrm{kDa}$, a species-specific protein antigen of $H$. pylori (O'Toole et al. 1991), in serum from gastric carcinoma patients when compared with those without the disease. This result is in accordance with that reported by Wang et al. (1998) in Taiwanese patients, who suggested that the $26 \mathrm{kDa}$ antigen may be used to screen gastric carcinoma patients. Other authors such as Yamaoka et al. (1998) and Holtmann et al. (1998) did not observe differences in the frequency of the serum low molecular weight bands between patients with and without gastric cancer. Since Mitchell et al. (1996) showed that an antibody response to this protein was one of the first to appear after infection with $H$. pylori in children, we may speculate that antibody to $26 \mathrm{kDa}$ protein could be a marker of prolonged infection, an essential step in the development of gastric carcinoma.

In regard to the duodenal ulcer patients submitted to the antimicrobial therapy, the results of the present study are in agreement with those obtained by Sörberg et al. (1997) and Kist et al. (1999) who detected anti-CagA antibodies in the patients' sera 32 and 12 months after successful treatment, respectively. In our study, $100 \%$ of patients had anti-CagA antibodies 1 year after eradication of the bacterium and antibodies could still be detected in 1 of $4(25 \%)$ of the patients evaluated 2 years after the end of the treatment. This result reinforces that serology is not adequate for monitoring treatment.

In conclusion the Helicoblot 2.0 is an accurate test to diagnose $H$. pylori infection and although it cannot be employed to monitor the bacterium eradication, the test may be useful for diagnosing past infection, especially in gastric carcinoma patients.

\section{REFERENCES}

Aucher P, Petit ML, Mannant PR, Pezennec L, Babin P, Fauchere JL 1998. Use of immunoblot assay to define serum antibody patterns associated with Helicobacter pylori infection and with $H$. pylori-related ulcers. J Clin Microbiol 36: 931-936.

Bardhan PK 1997. Epidemiological features of Helicobacter pylori infection in developing countries. Clin Inf Dis 25: 973-978.
Crabtree JE, Wyatt JI, Sobala GM, Miller G, Tompkins DS, Primrose JN, Morgan AG 1993. Systemic and mucosal humoral response to Helicobacter in gastric cancer. Gut 34: 1339-1343.

Ekström AM, Held M, Hansson LE, Engstrand L, Nyrén O 2001. Helicobacter pylori in gastric cancer established by CagA immunoblot as a marker of past infection. Gastroenterology 121: 784-791.

Faulde M, Cremer J, Zöller L 1993. Humoral immune response against Helicobacter pylori as determined by immunoblot. Electrophoresis 14: 945-951.

Figueiredo C, Quint W, Nouhan N, van den Munckhof, Herbrink P, Scherpenisse J, de Boer W, Scneeberger P, Perez-perez G, Blaser MJ, van Doorn LJ 2001. Assessment of Helicobacter pylori vac A and cagA genotypes and host serological response. J Clin Microbiol 39: 1339-1344.

Go MF, Kapur V, Graham DY, Musser JM 1996. Population genetic analysis of Helicobacter pylori by multilocus enzyme eletrophoresis: extensive allelic diversity and recombinational populations structure. J Bacteriol 178: 3934-3938.

Herbrink P, van Doorn LJ 2000. Serological methods for diagnosis of Helicobacter pylori infection and monitoring of eradication therapy. Eur J Clin Microbiol Infect Dis 19: 164-173.

Holtmann G, Talley NJ, Mitchell H, Hazell S 1998. Antibody response to specific $H$. pylori antigens in functional dyspepsia, duodenal ulcer disease, and health. Am J Gastroenterol 93: 1222-1227.

IARC-International Agency for Research on Cancer 1994. Infection with Helicobacter pylori. IARC Monogr Eval Carcinog Risks Hum 61: 177-240.

Karvar S, Karch H, Frosch M, Burghardt W, Gross U 1997. Use of serum-specific immunoglobulins A and G for detection of Helicobacter pylori infection in patients with chronic gastritis by immunoblot analysis. J Clin Microbiol 35: 3058-3061.

Kist M, Strobel S, Kirchner T, Dammann HG 1999. Impact of ELISA and immunoblot as diagnostic tools one year after eradication of Helicobacter pylori in a multicentre treatment study. FEMS Immunol Med Microbiol 24: 239-242.

Klaamas K, Held M, Wadström T, Lipping A, Kurtenkov O 1996. IgG immune response to Helicobacter pylori antigens in patients with gastric cancer as defined by ELISA and immunoblotting. Int J Cancer 67: 1-5.

Leung WK, Chow TP, Ng EKW, Chan FKL, Chung SCS, Sung JJY 2001. Validation of a new immunoblot assay for the diagnosis of Helicobacter pylori in the Asian population. Aliment Pharmacol Ther 15: 423-428.

Malaty HM, El-Kasabany A, Graham DY, Miller CC, Reddy SG, Srinivasan SR, Yamaoka Y, Berenson GS 2002. Age at acquisition of Helicobacter pylori infection: a follow-up study from infancy to adulthood. Lancet 359: 931-935.

Mégraud F 1996. Advantages and disadvantages of current diagnostic tests for the detection of H. pylori. Scan $J$ Gastroenterol 31: 57-62.

Mitchell HM, Hazell SL, Kolesnikow T, Mitchell J, Frommer D 1996. Antigen recognition during progression from acute to chronic infection with a cagA-positive strain of Helicobacter pylori. Infect Immun 64: 1166-1172.

NIH-Consensus Development Panel on Helicobacter pylori in peptic ulcer disease 1994. Helicobacter pylori in peptic ulcer disease. J Am Med Assoc 272: 65-69.

Nilsson I, Ljungh A, Aleljung P, Wadström T 1997. Immunoblot assay for serodiagnosis of Helicobacter pylori infections. J Clin Microbiol 35: 427-432.

O’Toole PW, Logan SM, Kostrzynska SM, Wadström T, Trust 
TJ 1991. Isolation and biochemical and molecular analyses of a species specific protein antigen from the gastric pathogen Helicobacter pylori. J Bacteriol 173: 505-513.

Park CY, Cho YK, Kodama T, El-Zimaity HMT, Osato MS, Graham DY, Yamaoka Y 2002. New serological assay for detection of putative Helicobacter pylori virulence factors. J Clin Microbiol 40: 4753-4756.

Parsonnet J 1995. The incidence of Helicobacter pylori infection. Alim Pharmacol Ther 9(Suppl. 2): 45-51

Queiroz DMM, Mendes EN, Rocha GA 1987. Indicator medium for isolation of Campylobacter pylori. J Clin Microbiol 25: 2378-2379.

Queiroz DMM, Mendes EN, Rocha GA, Oliveira AMR, Oliveira CA, Cabral MMDA, Nogueira AMMF, Souza AF 1999. Serological and direct diagnosis of Helicobacter pylori in gastric carcinoma: a case-control study. J Med Microbiol 48: 501-506.

Rocha GA, Oliveira AMR, Queiroz DMM, Mendes EN, Moura SB, Oliveira CA, Ferrari TCA 1998. Serodiagnosis of Helicobacter pylori infection by Cobas Core ELISA in adults from Minas Gerais, Brazil. Brazilian J Med Biol Res 31: $1263-1268$.

Rocha GA, Oliveira AMR, Queiroz DMM, Carvalho AST Nogueira AMMF 2000. Immunoblot analysis of humoral immune response to Helicobacter pylori in children with and without duodenal ulcer. J Clin Microbiol 38: 1777-1781.

Sörberg M, Engstrand L, Ström M, Jönsson KA, Jörbeck H, Granström M 1997. The diagnostic value of enzyme immunoassay and immunoblot in monitoring eradication of Helicobacter pylori. Scan J Infect Dis 29: 147-151.

Wang JT, Chang CS, Lee CZ, Yang JC, Lin JT, Wang TH 1998. Antibody to a Helicobacter pylori species specific antigen in patients with adenocarcinoma of the stomach. Bioch Bioph Res Commun 244: 360-363.

Wotherspoon AC 1998. Helicobacter pylori infection and gastric lymphoma. Br Med Bull 54: 79-85.

Yamaoka Y, Kodama T, Graham DY, Kashima K 1998. Search for putative virulence factors of Helicobacter pylori - The low molecular-weight (33-35 K) antigen. Dig Dis Sci 43: 1482-1487. 